\title{
A semiotic approach to language ideologies: Modelling the changing Icelandic languagescape
}

\author{
Stephen Pax Leonard ${ }^{1}$
}

\begin{abstract}
Attempts have been made to examine how speakers frame linguistic varieties by employing social semiotic models. Using ethnographic data collected over many years, this article applies such a model to Iceland, once described as the 'e-coli of linguistics' - its size, historical isolation and relative linguistic homogeneity create conditions akin to a sociolinguistic laboratory. This semiotic model of language ideologies problematizes the prevailing discourse of linguistic purism at a time of sociolinguistic upheaval. The analysis shows how an essentializing scheme at the heart of Icelandic language policy ensured that linguistic "anomalies" such as "dative disease" and "genitive phobia" indexed essential differences. "Impure" language was indicative of un-Icelandicness. Once monolingual (indeed monodialectal), the Icelandic speech community is increasingly characterized by innovative linguistic transgressions which thus far have not been instrumentalized by language policy makers. It is shown how a semiotic model can help us analyse the function of language ideologies more generally.
\end{abstract}

Keywords: language; ideology; semiotics; Icelandic; purism

\section{Introduction}

The language ideology of Iceland has been one of ethnolinguistic nationalism (one nation-one language) since possibly medieval times (Leonard, Árnason 2011). Iceland has also been characterized by an ideology of linguistic continuity (Leonard 2011; 2012) - Icelanders feel this supposed linguistic continuity since the time of the Settlement in the ninth century renders them unique among the community of Scandinavian nations. These language ideologies that for years have been implicit in policies of linguistic purism might for the first time face a new set of challenges. Once monolingual, Iceland is becoming "surface

1 Moscow State Linguistic University, Ulitsa Ostozhenka 38, c1, Moscow 119034; Institute of Linguistics and Intercultural Communication, I. M. Sechenov First Moscow State Medical University, 3-1 Sadovaya Kudrinskaya St, Moscow 123432, Russia. E-mail: stephen.leonard@1msmu.ru. 
multilingual" and this language of 320,000 speakers is facing "digital minoritisation" (Sigurjónsdóttir et al. 2017). ${ }^{2}$ The language of digital domains is increasingly English, and not Icelandic. ${ }^{3}$ As an example of digital minoritization, I encountered during my research young Icelanders who just switched to English to play video games, engage in online role play and develop their own virtual worlds. Such changing trends in language use suggest Iceland might be moving away from an "imagined" (Anderson 1991: 42) and idealized monolingual norm.

The broad question relevant to semiotic theory I am asking in this article is: how do speakers frame their understanding of linguistic varieties? I will answer this question with reference to as yet unpublished data from Icelandic. Icelandic has been described by Chomsky as the 'e-coli of linguistics' for its size, historical isolation and linguistic homogeneity permits us to test interesting linguistic hypotheses and models. To that end, the point of this article is specifically to test a semiotic model of language ideologies (Irvine, Gal 2000) in the Icelandic sociolinguistic laboratory in order to see whether it can be applied subsequently to larger and sociolinguistically complex languages. In doing so, I am concerned not just with the structure of ideologies, but also, and especially, with their consequences. My analysis shows how such a social semiotic model can help us understand better the function of language ideologies. The case of Iceland proves that the modelling of linguistic ideologies in semiotic terms can be very effective, and is therefore likely to be so in larger speech communities.

Links between linguistic forms and social phenomena have been subject to a very widespread discussion since Silverstein (1979: 193) first defined the sub-field of "ideologies of language" as "any sets of beliefs about language articulated by the users as a rationalization or justification of perceived language structure and use". Increasingly, there has been a tendency to view language ideologies as complex and multiplicitous (Briggs 1998; Irvine, Gal 2000; Kroskrity 1998; Ochs 1996; Vygotsky 1962; Woolard 1998). Kroskrity and Field (2009: 6) claim for instance that speakers have multiple ideologies of language and that this is a reflection of the plurality of social divisions. However, the culturally homogenous language ideology of Iceland with so few social divisions is no fallacy. A small population endorses - overwhelmingly, in fact - a single ideology of language (Leonard 2011; 2012) for Iceland has been a rather static, uniformly shared culture. There is relatively little "indexical mutability" (Eckert 2012: 93-97) in Iceland. Yet that is about

2 By 'surface multilingual', I mean that an ever larger number of languages are spoken in Iceland, but it is not yet clear whether these migrant speech communities will stay for the longer term and become established in Iceland or not.

3 Apple and Amazon do not support Icelandic and not one of my interlocutors used Windows in Icelandic. 
to change, and perhaps dramatically. As we will see, those who have recently settled in Iceland are unlikely to subscribe to what might be described as Icelandic linguistic evangelism; there will be new challenges to the ideological conformity. The migrants will not be embedded in the linguistic culture in the same way for attitudes to the valorization of linguistic purism are not universal.

To ensure that sociolinguistic and dialectal variation remained minimal in Iceland, variants were previously "erased" through a puristic language policy or at least attempts were made to "erase" them. As an example, flámoli or "slackjawed speech" was at various times a common phonological variant in eastern and south-western Iceland. Speakers affected by flámøeli made little or no distinction between ' $i$ ' and ' $e$ ' or between ' $u$ ' and ' $\dddot{o}$ ', particularly if these vowels were pronounced long. The case of flámeli appears to be a rare example of language policy eradicating a sociolinguistic variant (the speakers of which were considered "degraded"). Variants were not "erased" in the sense they were not acknowledged. On the contrary, Icelandic radio programmes (such as Daglegt mál) discussed these anomalies and ran campaigns to stigmatize these "errors". ${ }^{5}$ They were erased in the sense some variants were essentialized and considered a 'linguistic other'. Anderson's (1991) notion of 'imagined communities' is relevant in this regard. As Cameron (2006) notes, Anderson (1991) placed language outside the sphere of the ideological, but this article works on the premise that national languages can be "imagined" as well; "imagined" to be "pure" and "homogenous" in this case. All communities have values and beliefs about their languages. Historically, in Iceland "correctness" has been honoured over sociolinguistic variation and linguistic forms are treated as an index not only for social groups, but the whole nation. Language and nation are co-terminous in Iceland for language acts as a totem for the Icelandic nation (Pálsson 1989). This firm belief in a canonical form of language is a feature of "standard language cultures" (Milroy 2001: 535) of which Iceland is a good example. It is at the level of linguistic differentiation that Icelandic discourse engages ideologically embedded processes such as the "ideology of standardization" whereby speakers in "standard language cultures" believe their languages to exist in standardized or uniform forms. These misguided beliefs are important for they provide a link between linguistic forms and social structures.

4 Flámoeli is of interest for another reason. Icelandic linguistic purism tended to focus on syntax and morphology. They wanted to maintain the "thread" by ensuring the grammar of the saga period did not change. But here we have an example of "phonological sickness" even though we cannot be sure how the Viking settlers spoke.

5 Daglegt mál was an Icelandic radio programme that started in 1978 and broadcast every Monday and Friday evening. The programme discussed all aspects of the Icelandic language. 
This article is organized as follows. First, consideration is given to the theoretical considerations vis-à-vis the modelling of language ideologies, in particular the specific features of Irvine and Gal's (2000) model. Then, the methodology I used for collecting my data is explained before examining the Icelandic linguistic practices borne from the data I collected. Finally, the results of the data concerning "new" linguistic practices in Iceland are discussed before analysing how the Irvine and Gal model might be made more relevant to sociolinguistic developments elsewhere.

\section{Theoretical considerations}

Irvine and Gal (2000: 35-83) developed a model that uses semiotic processes to explain how ideologies of language treat linguistic differences and rationalize sociolinguistic complexity. In this article, the model will be used to examine not how ideologies of language account for sociolinguistic variation, but, rather, how ideologies of language rationalize sociolinguistic homogeneity in the case of Iceland. ${ }^{6}$ By using ethnographic data to examine the manner in which language is used in the "social world" (Kroskrity 2004: 498) of Icelanders, we will see that a semiotic analysis can be used to problematize a discourse of linguistic purism at a time of sociolinguistic upheaval. In doing so, it will become clear which semiotic processes could be used to understand the ideological function of language policies more generally. The same model of semiotic linguistic ideologization has been used to show how semiotic processes can be used to unpack how certain linguistic features are perceived as "deviant" and are portrayed as inherent icons of their speakers in terms of age and ethnicity (Androutsopoulos 2010: 182-205). Irvine and Gal's model of semiotic linguistic ideologization has also been widely used in studies of media discourse (Horner 2007; Thurlow 2017: 10-19; Milani 2008). In the latter, the lack of spoken Swedish amongst migrants appears as an icon of some sort of 'invandrarskap' ('immigrant-ness').

Irvine and Gal's model uses Peircean semiotics to show that ideological representations of linguistic differences are based on three processes: (1) iconization; (2) fractal recursivity and (3) erasure. Iconization is a semiotic transfer between linguistic features and social image where linguistic features that index (point to) social groups appear to be iconic representations of them. Languages and the way

6 Irvine and Gal (2000: 36) make it clear that they are concerned with the "dynamics of a sociolinguistic process", and thus I think it is legitimate to use the model to discuss how ideologies treat the perceived lack of sociolinguistic differences (as well as the differences themselves) for both of these outcomes imply "processes". 
they are spoken can become indices for a whole range of factors (socio-economic, political beliefs, religious beliefs etc.). Iconization works by giving the impression that a linguistic feature represents the inherent nature of a social group. Iconization is pervasive in linguistic ideologies that reflect the marginalization of the 'other'. Andronis (2003: 263-69) gives the example of the linguistic ideologies of Serbian speakers who iconize the simpler nominal morphology of Macedonian to represent the speakers of the latter as "country bumpkins". Fractal recursivity involves the projection and reproduction of an opposition at some other level, creating new dichotomies and sub-categories: "an intragroup opposition might be projected outward onto intergroup relations" (Irvine, Gal 2000: 38). The idea behind fractal recursivity is that the same oppositions that distinguish given groups from one another on larger scales can also be found within those groups. Fractal recursvity can create a new group identity at a certain level, but also divide it. Erasure is the process whereby certain sociolinguistic phenomena are rendered "invisible" and explained away as they are inconvenient to the totalizing language ideology. Erasure is the "stripping of details from the ideological picture" (Anroutsopoulos 2010: 197): ideological outliers are discounted or ignored. Intertwined with iconization and fractal recursivity, Irvine and Gal (2000) present erasure as the process by which distinctions are created and maintained.

This semiotic model can be used to show how any conceptualization of language is deeply entrenched in the broader cultural images of its speakers. Employing this tripartite model, we will see that the "imagining" of linguistic continuity and homogeneity can be rationalized effectively in semiotic terms. In Gal and Irvine $(2019: 85,138)$, the authors' work on the semiotics of differentiation is extended and taken in new directions by showing how understandings of social life (and not just linguistic practices) are also based on how differentiations are reflected and effected. Both language and social action require a semiotic basis.

In Iceland, iconization (as defined above) emerged in the linguistic descriptions of language policy makers in the 1970s and 1980s: linguistic "anomalies" such as "dative sickness" (discussed in Section 4 below) were subject to a certain interpretive structure and perceived to be emblematic of supposed essential differences. The "errors" had to fit the essentializing scheme which underpinned the language policy. Language was seen as an index of syntactic and morphological purism. Language policy was guided by an attempt to essentialize Icelandicness as something homogenous. An ideology of societal monolingualism (indeed monodialectalism) where a language is perceived to correspond with essentialized representations of social groups has to find ways of rendering variation anomalous.

However, before we test the model in light of the evidence from Icelandic, we might ask why we need to model language ideologies. There could be various 
motivations for modelling linguistic ideologies: if we can understand better how people construct ideological representations of linguistic differences, we are likely to have a better grasp of the mechanisms that are used to discriminate against people on grounds of language usage. We will be in a stronger position to implement fair and equitable language policies as communicative practices adjust to increasingly multilingual speech communities. Before we look a these communicative practices in more detail, let us first turn to the methodology of data collection employed in this research.

\section{Methodological considerations}

The data for this article was collected over three separate ethnographic fieldwork trips spanning a nine-year period. My interest in linguistic ideologies arose during my first period of fieldwork in the summer (mid-May until mid-September) of 2008 when I came across the phenomenon of grammatical correction. I collected qualitative data through participant observation; as well as both qualitative and quantitative, non-experimental empirical data through interviews on language attitudes with a specific focus on Icelandic language policy, linguistic insecurity and linguistic conservatism. My data was borne from my empirical observations: collections of instances of language in use; subjective responses to certain linguistic behaviour and speakers' self-reports on their language use. I employed the ethnograhic approach because I wanted to discover how people use language, what they think about it and why they hold these beliefs (Heller 2008: 250).

During my participant observation fieldwork, I lived on a horse farm in southern Iceland. The reason for choosing this particular fieldsite was that Icelandic farmers as 'communities of practice' (Lave, Wenger 1991) are considered the most linguistically conservative speakers of Icelandic. I also conducted ethnographic work in restaurants and cafés in Reykjavík which were employing non-native speakers of Icelandic in 2017. Sociolinguistically, this fieldsite was at the other extreme from horse-farming and characterized by translanguaging discursive practices. I travelled to all parts of the country to speak with Icelanders. Everybody I met was keen to talk to me about sociolinguistic issues. In total, I interviewed 75 people from all over Iceland. About 60 per cent of my informants were women and my interlocutors represented all different age groups (from 13 year olds to 82 year olds). The recorded interviews were normally informal but structured using the informed consent procedure. Some interviews were quite unstructured, however. Icelanders (particularly elderly ones and politicians) like to meet at the hot-tubs early in the morning. The Icelandic hot-tub is akin to 
the British pub, the French café or the Russian bathhouse. This became a fruitful venue to do fieldwork on language attitudes. My respondents did not feel the "pressure" of a formal interview and I could observe the interactions with fellow bathers, all of whom were keen to engage in discussions on linguistic conservatism. In the first part of the fieldwork, the tropes most frequently invoked by my interlocutors were purism, linguistic insecurity and grammatical correction.

Two subsequent field-work trips were completed in 2014 and 2017. In these two shorter trips, I asked similar questions of Icelanders to determine how attitudes to language ideologies were evolving in a period of change. During these years, Iceland experienced an unprecedented increase in tourism and migration. In these later two field trips, Icelanders spoke frequently about "change" and the challenges that the Icelandic language would face in the future. Language endangerment and 'stafrena minnihlutagervingu' ('digital minoritization' - "when a majority language in the real world becomes a minority language in the digital world") was mentioned in the discussions. ${ }^{7}$ There was a consensus that Icelandic language policy had become less prescriptive and puristic and that this was a good thing. Despite what some perceived to be multilingualism taking root in Iceland, the views about the "uniqueness" of the Icelandic language were very much unchanged irrespective of the age of the interlocutor. The comments made during these interviews formed the basis for this article, but they were complemented by ethnographic observations made about unexpressed assumptions that "implicitly framed the discussion" (Woolard 1998: 9). Those I interviewed had little to say about the effects of language contact. Those few who believed the future of the language was uncertain felt that Icelanders might switch to English as opposed to going through the conventional stages of language death. Some reported that this switch from Icelandic to English is already underway in school playgrounds where conversations amongst children/teenagers revolve around social media, gaming and Smartphone Apps. About 15 per cent of the conversation between all the teenagers I worked with was in English.

The level of "risk" to my interlocutors in these interviews was low, but nonetheless pseudonyms have been used to protect their identity. Full risk assessments were undertaken prior to the research in accordance with university guidelines and great care was taken to ensure that I met all the fieldwork ethical standards required by the institution with which I was affiliated at the time.

7 See Sigurjónsdóttir et al. 2017, and Rehm, Uszkoreit 2012 which states that 21 European languages face digital extinction. 


\section{Icelandic linguistic practices and language ideologies}

Ideology systematically links language and society. By ideologies of language, I mean a set group of ideas about language that are subconsciously promulgated through a community of people. It is a set of ideas and beliefs about what language "is". Contrary to what Woolard and Schieffelin (1994: 55-82) state, linguistic ideology does not have to be rooted in multilingualism. What is more, as many have observed (Irvine, Gal 2000: 35-83; Kroskrity 2010; Silverstein 1979), ideologies of language are never just about language, but "envision and enact ties of language to identity, to aesthetics, to morality, and to epistemology" (Woolard 1998: 3). They are about "talk" and the series of socio-historical structures behind the "talk" which serve to create an identity for speakers through ideologized discourse. For instance, there has been a tendency to gloss over the Celtic influence on Iceland's history and language. DNA evidence shows that the majority of female settlers to Iceland were Celtic (probably slaves of the Vikings and presumably Celtic-speaking), but the manuscripts and subsequent histories of Iceland seldom mention them. ${ }^{8}$ Cultural phenomena have been rendered less visible or "erased" in accordance with the Irvine and Gal model because they might represent inconvenient linguistic facts. When discussing Iceland's linguistic history, the essentialized linguistic and social categories are made to seem isomorphic: the Icelandic language with its apparent minimal evidence of a Celtic substratum is used as testimony of where Icelanders have come from. Language is mapped directly onto culture. What some perceive to be the air-brushing of the Celtic substratum is complemented by cultural images of a Viking heritage which are used to legitimize linguistic continuity (Old Norse/Icelandic was the language of the Vikings) and invoke tropes of linguistic authenticity. ${ }^{9}$

Neologisms coined by language policy makers also feed into this trope of linguistic authenticity. Neologisms have been an important part of the puristic language policy in Iceland (Leonard, Árnason 2011: 91-96). These new coinages leverage off Norse verbal and nominal roots and are coined to match the normative isomorphic representation of language, nation and culture. ${ }^{10}$ By doing so,

8 Helgason's (2000a: 999-1016; 2000b: 697-717) genetic research found that 62 per cent of Icelandic women have Irish ancestry whereas 80 per cent of the male population had a Norse lineage.

9 Before the 2008 financial crisis that crippled Iceland, the Icelandic businessmen that had bought up much of the British High Street in previous years were labelled 'útrásarvíkingar' ('Vikings that conquer new lands').

10 One such example might be 'tölvapóst' ('e-mail'; literally 'post from the number prophetess'). Tölva is the neologism for 'computer' (tala 'number' + völva 'a figure that appeared in the sagas and predicted your future'). The first computers in the 1980s were seen as machines throwing out numbers at random. 
the folk ideology of linguistic continuity is perpetuated and Icelanders are led to believe they "speak the language of the Vikings":

Extract from interview with Katrin about language attitudes. Katrin is a 52-yearold woman who lives in Akureyri, northern Iceland. (Translated from Icelandic.) Author: What for you is the appeal of the Icelandic language?

Katrin: The Icelandic language is an ancient language. The language tells us everything, our history, our culture, our identity, our sense of who we are. It shows us where we came from. We must preserve that. If we lose our language, we will no longer have a bond with our roots. We would have no anchor.

According to such accounts (these opinions were expressed repeatedly), language ideology and policy in Iceland is thus a means of national(ist) self-explanation. It is not so much an attempt to maintain the hegemony of the nation-state (Bauman, Briggs 2009; Hansen et al. 2018), but more a case of the discourse of purity being used as a means to maintain the nation as a culturally homogenous entity. As we will see, the discourse works by invoking folk rationalizations and oppositions, leveraging off the tendency to dichotomize human behaviour (here verbal behaviour) into acceptable and non-acceptable categories. These patterns can be just considered a consequence of iconization. They are not necessarily fractally recursive patterns "recurring at progressively smaller scales" (Irvine, Gal 2000: 35-38). As an example, one such debate on linguistic purism in Iceland in the late 1970s showed that the purists described Icelanders who made grammatical or lexical errors as "diseased", i.e ideologically laden language indexing pathogenic organisms was used to describe speakers who uttered grammatical "mistakes". ${ }^{11}$ By using systems of dualistic symbolic classification indicative of taboo (healthy versus diseased), the objective was to stamp out speech habits that threaten the "linguistic thread" by associating them with dirt, pollution, blemishes, stains (the so-called 'sléttur') etc. It is not clear, though, whether these patterns were replicated progressively at smaller scales, and how exactly it would manifest itself if they were:

Extract from interview with Eva about language attitudes. Eva is a 64-yearold woman who lives on a horse farm in southern Iceland. (Translated from Icelandic.)

Author: Why do you think linguists and language policy makers referrred to grammatical "errors" in terms of diseases and sickness?

Eva: There was a real anxiety about the language at the time. Actually, I think there always has been in Iceland. As we are so few, there has always been this sense that the language could die. I think these people were determined to try and

$\overline{11 \text { See Kvaran } 2005}$ for a full discussion on this point. 
maintain the older language, the language of the sagas. They felt that by labelling these grammatical mistakes as 'sicknesses' they would encourage people to stick to the norm of the sagas which has always felt to be 'correct'. They wanted to stamp out these practices, and not let them become established. But I think with this one, it back-fired, you know. These 'incorrect' grammatical forms are widespread now. We have all become sick! (she laughs)

Author: Why has language policy been so against the acceptance of foreign words in the language?

Eva: For us Icelanders, it is language that defines us. It is our language that sets us apart, that reminds us of our Viking roots. If the Icelandic language accepts lots of English words, the boundaries become blurred. We are no longer sure where we are, and perhaps we forget where we have come from. Without the Icelandic language, there is no Icelandic nation. I think most Icelanders believe that.

As previously mentioned, one well-known concern of language policy was the so-called "dative sickness". The syntactic phenomenon of dative substitution, 'págufallssýki', has been widely discussed in the literature. ${ }^{12}$ Dative sickness is the tendency for accusative subjects to be put in the dative. An example of this phenomenon is 'mér (dat.) langar að fara' ('I want to go') instead of 'mig (acc.) langar að fara' ('I want to go'). ${ }^{13}$ This substitution can sometimes affect the nominative too, as in the example, 'mér (dat.) hlakkar til' ('I am looking forward to'), instead of 'ég (nom.) hlakka til' ('I am looking forward to'). Gísli Pálsson (1989: 121-39) has discussed the terminology used to describe this and other grammatical mistakes. Such (relatively minor) grammatical discrepancies were described by employing metaphors of pathogenic organisms. Pálsson (1989: 130) notes that "standard language" is regarded as "pure" ('hreint') language, while non-standard language is seen to be pathological or the result of some kind of contamination. ${ }^{14}$ We can see how language and this essentialised thinking is anchored in dualistic thought. If language is not "pure" ('hreint' can also mean 'clean'), it is by definition "impure" or "dirty". This seems to fit Irvine and Gal's model where syntactic

12 See Svavarsdóttir 1982: 19-62; Rögnvaldsson 1983: 3-6; Pálsson 1989: 121-39.

13 One of the oldest Icelandic manuscripts, the Old Icelandic Homily Book (Stock. Perg. 4to no 15.) contains the form 'ég (nom.) langa' which, using the same logic, would amount to the 'nominative disease'.

14 One might note that the so-called "pure" Icelandic, the language of the Saga Age, was almost certainly based on the speech of a levelled dialect of south-west Norway (Leonard 2011: 169-86). This speech was in no way "pure" in the sense of being homogenous and free of external influences. On the contrary, there was a Celtic influence as evidenced in place names and personal names. Subsequently it came to be thought of as a benchmark of "pure" Icelandic as over the centuries the texts and manuscripts of this period became the defining feature of cultural Iceland. 
features appear as iconic representations of social groups: the implication was that these speakers should be seen as "outsiders" for this was not how Icelanders spoke. The ideological representation - itself iconic - was made to feel inherent. Speaking a language full of such morphological "errors" was seen to be iconic of tarnished thought; linguistic "impurities" were icons of muddled thinking. ${ }^{15}$ Not only were the grammatical features anomalous, but the speakers were too. Such terms as 'dative disease' and 'genitive phobia' ('eignarfallsflótti') were widely used and understood by the general public. ${ }^{16}$ Eignarfallsflótti is where speakers use the dative or the nominative instead of the genitive. An example might be 'gjöf drottningu' ('gift of the Queen') instead of 'gjöf drottningar' with the genitive ending. There was a widespread acceptance that such variations in language and linguistic changes could be interpreted in terms of bacterial transmission. Moreover, the understanding was that the rules of grammar were correlated to the rules of society: language is the cultural diacritic of society (Rampton 1998).

Over time, these morphological "errors" have become increasingly common. One male informant in his fifties living in Reykjavík told me that "bardaginn við págufallssýka hefur tapast" ("the battle with the dative disease has been lost"), and that would seem to be the case. My interviews included a number of examples of "dative disease" and "genitive phobia". These morphological features may have been 'iconized', but they have over time lost their ideological salience and currency as their use became rather widespread and the stigma faded. Nowadays, there are relatively few speakers who worry about the "dative disease" in their speech.

A more recent syntactic innovation (the "new passive") does not appear to have been iconized in the same way as "dative sickness" was. With the "nýpolmynd' ('new passive') there is no participial agreement in impersonal passives. An example of this kind of construction might be: 'pað var lamið mig' ('it hit me') (Sigurjónsdóttir, Maling 2001: 123-80) instead of 'ég var laminn' ('I was hit'). Here we have the expletive ' $p a ð$ ' which is inserted as a place-holder before the finite verb. This kind of innovative construction where a passive auxiliary and participle is able to assign accusative case represents a significant syntactic change and a bona fide example of sociolinguistic (and also regional) variation. ${ }^{17}$ Research

\footnotetext{
15 It is worth noting that even as early as 1984 some Icelandic linguists opposed the policies of linguistic purism. In a 1984 episode of the Daglegt mál radio programme, Eiríkur Rögnvaldsson questions the use of having a "pure" language that nobody can use: "Hreint mál sem enginn kann að nota er minna virði fyrir litla pjóð en mál [...]" ("A 'pure’ language that nobody can use is less value to the nation than a language [...]").

16 See Kjartansson 1979: 88-95 for a more complete discussion.

17 Sigurjónsdóttir and Maling (2001: 129) show that there is a marked difference in usage between West Reykjavík and the rest of Iceland.
} 
shows that it is being used very widely and almost exclusively by teenagers. One of my female teenage interlocutors said during an interview: "Pað er drepið sjálfan sig" ('people take their own lives') instead of "Fólk drepur sjálfan sig". A number of older (above the age of 40) informants told me that they were unable to understand some of these constructions. ${ }^{18}$ A survey by Maling and Sigurjónsdóttir (2002: 97-142) confirmed that new passive sentences are perceived to be ungrammatical in the standard language with only four percent of adults judging similar sentences acceptable, compared to 70 percent of young people. Unlike in the 1980s, these syntactic irregularities do not appear to be the focus of any language campaigns. The new passive has not been subject to the prescriptive purism in the way that the "dative sickness" was. Older generations who do not use this syntactic form view it as an oddity, but its recursive indexical properties are less apparent. It does not have the social iconic significance that it would have had thirty years ago and this is a reflection of a shift in linguistic ideologies and also language attitudes.

Applying the notion of purity to language might seem a peculiar undertaking for one is associating an abstract notion to something which does not represent physical dirt. One cannot compare it to a purification ritual where there might be an act of washing. The idea behind this classification is of course to create symbolic categories through the process of iconization, and taboo is characterized by associations through analogy (Valeri 2000: 48). As Douglas (1966: 36) points out in her classic work on pollution and taboo, "where there is dirt, there is a system. Dirt is the by-product of a systematic ordering and classification of matter, in so far as ordering involves rejecting inappropriate elements". Linguistic purism aims to induce this kind of symbolic, antithetical thinking. In turn, it is hoped that this symbolic thinking and taboo associations will lead to avoidance. For this to work, the so-called "pure" Icelandic of the Saga Age must be endowed with a certain kind of Durkheimian "sacredness" (Durkheim 1912). Thus, language policy in Iceland is focused on preserving an archaic norm. For purism to thrive, this rigorous opposition must be accepted by speakers and if certain linguistic forms can appear as "sacred", then the opposition, for some at least, will have more appeal.

Icelandic needed to be "imagined" as "homogenous", and in order to achieve this perception internal variation had to be "erased". It was felt sociolinguistic and dialectal diversity would have undermined the Settlement identity of Iceland whereby the first settlers were perceived as some kind of prototypical, homogenous Norsemen (Leonard 2011: 169-86). As elsewhere, ideologies of language

18 More research needs to be done to understand sociolinguistic patterns of usage for these constructions, but such developments and others are likely to show that there is more sociolinguistic variation in Icelandic than Icelanders wish to admit. 
in Iceland are intimately linked to identity. Language ideologies are used by Icelanders to represent an identity of social and linguistic exceptionalism. The narrative of linguistic continuity in Iceland becomes part of the fetishization of the perceived linguistic uniqueness and boundedness. An ideology of linguistic continuity indexes the cherished link with Iceland's foundational golden age (gullaldarmálsin) of saga literature (The Sagas of the Icelanders written in the 12th and 13th centuries) allowing the relationship between language, literature and national identity to arise dialectically (Joseph 2004: 124). This dialectal relationship makes it difficult to prize apart language and ideology (Voloshinov 1972) as such an analysis might hope to do.

At another level, sociolinguistic variation also problematizes the notion of a classless society (Pálsson 1989: 121-39). Tropes of equality and egalitarianism are ancient, date back to the Saga Age and are the sociological bedrock of Icelandic society. ${ }^{19}$ However, my research showed that speakers were not aware that what one might call "progressive" discourses regarding equality sit at odds with what might be perceived as "oppressive" ideologies that devalue language varieties:

Extract from interview with Ólafur about language attitudes. Ólafur is a 71-year-old man who lives in Reykjavík. (Translated from Icelandic.)

Author: In what way is the Icelandic language changing?

Ólafur: It is changing fast ( Раð er að breytast hratt, with special emphasis on breytast 'changing'). It is still one language that binds us. There are no dialects. Just a couple of different sounds. But, the young people, their [his emphasis] language is changing so fast. Sometimes I do not understand it. They use strange constructions. The grammar is wrong. Many use more and more English words. It is not Icelandic.

As we will come to see, a policy of linguistic purism jars somewhat with egalitarian tropes for it creates (perhaps via fractal recursivity) a new set of social dichotomies based on the essentializing of sociolinguistic data. Previously, these apparent chinks in the ideological armour were overcome by labelling anglicisms and morphological innovations as "errors", and not Icelandic. The hegemonic language ideology was thus not jeopardized in any way and local beliefs about the language's homogeneity could continue to be internalized.

My research also showed that sometimes certain Icelanders who hold what some might call hegemonic linguistic ideologies in the sense they believe that there could be only one language in Iceland inadvertently used language that

19 Evidence from the sagas shows that women managed the finances of the household, ran the farmstead in the absence of the husband, and often became wealthy landowers if they were widowed. 
conformed to counter-hegemonic norms. One male informant (Gunnar) in his late teens living in western Iceland told me how he thought it was important to "preserve the ancient language" before turning round to his mother who took a phone call on his behalf and saying: "Ég mun tala við blókina seinna. Dað er ekkert smá djobb." ("I will speak to the bloke later. It is not a small job”). 'Blók' ('bloke') and 'djobb' ('job') are anglicisms that feel conspicuously foreign to an Icelander, and that would be categorized by many Icelanders as sléttur (a pejorative description meaning literally 'blemishes' or 'stains').

For such interlocutors, a hegemonic linguistic ideology was an ideal that was compromised in speaking practices which employed the same "icons of foreignness" (Irvine, Gal 2000: 46) that they were rejecting. In some of my interviews, Icelanders spoke to me about the purity, homogeneity and immutability of their language, but in the same breath used an anglicism. These ideologies are constantly articulated, but not always "read from actual use" (Kroskrity 2004: 505). Hill (1985: 725-37) found the same thing among Nahuatl speakers.

\section{New communicative practices in a rapidly changing "languagescape"}

As we have seen, Iceland has been characterized by monolingualism, but the significant increase in migration and exponential growth in tourism means that the Icelandic "languagescape" (Pratt 2011:279) is a very different one from that just 20 years ago. There were up until recently over two million foreign visitors to Iceland each year (many of these are simply passing through Keflavík airport). When I first went to Iceland in 1999 , there were just $262,000 .{ }^{20}$ Iceland is a small, rather homogenous speech community that is exposed to great waves (particularly with the influx of tourists in the summer months of June-September) of largely seasonal multilingualism. In that sense, Iceland shares perhaps some features with Labov's (1972: 1-41) Martha's Vineyard even if the visitors and residents of Martha's Vineyard both tend to be native speakers of American English.

During the months of June-September, the Icelanders are outnumbered by speakers of other languages to the extent that Icelandic is perceived as a minority language by the visitors even if it is the only official language. ${ }^{21}$ Today, over 100 languages are spoken in Iceland. ${ }^{22}$ Languages such as Polish, Albanian, Filipino,

20 Figures are from the Icelandic Tourist Board (https://www.ferdamalastofa.is/en/recearchand-statistics/numbers-of-foreign-visitors).

21 A number of tourists I met during the fieldwork told me they believed the language of Iceland was English.

22 See Hilmarsson-Dunn, Kristinsson 2013: 210. 
Vietnamese, Russian, Lithuanian and Spanish have admittedly few speakers in Iceland, but nonetheless migrants speaking these languages have all settled there over this very short period. I analysed the speech practices of some of these new speech communities in the capital, Reykjavík. Translanguaging (García, Wei 2013; Wei 2011), where speakers draw on a multilingual and "embodied" pool of semiotic resources to communicate, has become the discursive norm for some of these migrant families that have recently settled in Iceland. Translanguaging operates in unstandardized situations and implies that language boundaries are indeterminate. Despite the monolingual language ideologies, some recent migrants to Iceland are busy constructing shared, counternormative translanguaging spaces. Here is an example from a conversation in a restaurant kitchen in Reykjavík between two Russian girls who had been living in Iceland on and off for 18 months. Translations are in brackets: ${ }^{23}$

\section{Extract from conversation:}

Maria: How many coffees do they want?

Olga: Три. Нет, четыре, я думаю. ('three. No, four, I think')

Maria: Allt í lagi (Alright). Give те пять минут plís. (Give me five minutes please) Olga: Takk fyrir (Thanks). What is the name of the new девушка (girl)? Ты знаешь? (You know?)

Maria: I forget. Kristin. Может быть? (Maybe?)

In line three, you can see how the girl uses English, Russian and Icelandic slang (plis) in the same sentence. For what has been a rigid monolingual language ideology, these are extraordinary developments. Or, are they? Baynham and Lee (2019) claim that translanguaging emerged in reaction to another kind of normativity - the ideology of monolingualism. ${ }^{24}$ This is perhaps a response to a static synchronic language ideology. Here, conversation instead becomes a dynamic space with competing centres of normativity in a multilingual matrix. It might appear that these practices are unique to non-native speakers, and that Icelanders would not mix languages or code-switch in such a manner. However, my evidence suggests otherwise.

\footnotetext{
23 Some may consider such an exchange to be indicative of code-switching and not translanguaging. Working with these informants, my impression was they were drawing on a multilingual repertoire and not just systematically switching codes. The definitions of these terms are not precise.

24 However, translanguaging might be perceived as a language ideology in itself for it implies a monolingual norm is socially constructed to exert power (Heller 1999), and arguably serves to disaggregate named monoglossic entities such as English, Icelandic etc.
} 
Increasingly, young Icelanders are also transgressing linguistic boundaries and using English in certain contexts: for example, the playing and subsequent discussion of interactive video games and mobile phone app games. With the example of interactive video games, young Icelanders interact virtually in English with nonnative speakers all over the world as well as with the characters themselves. Here is an extract from a recording with Jón and Sigurður (both aged 14) playing Godzilla Unleashed:

Jón: Sko, go into the tunnel now. I go round and wait the other end.

Sigurður: Já, I am in. Get ready for battle, vinur minn. Here we go. Where is the monster? That's weird.

Jón: Veit ekki. [...] Oh, my God, here he comes! Shiit. He’s enormous. This is psycho. Sigurður: Alright, we can do this. Wait til he gets closer. OK. Ready? Shoot. Now. Jón: Awesome. Watch out for the missiles. They are gunna hurt, if they hit us.

If this were a piece of conversation analysis (CA), the aim might be to analyse the function of Icelandic (not English) in the dialogue for all these conversations I recorded in this context were predominantly in English. ${ }^{25}$ In this "juxtaposition of semiotic systems" (Auer 1995: 116), the language of the game world is English with just the occasional tag in Icelandic: 'sko' ('look'), 'vinnur min' ('my friend'), 'já' ('yeah'), 'veit ekki' ('I don't know'). Not only is the language of the game world English, my research with Icelandic teenagers showed that subsequent conversations about gaming between Icelanders would increasingly include whole sentences in English. As the average Icelander spends about an hour a day gaming, there is inevitably more and more English being spoken. For a country that has a history of policing linguistic borders, language policy makers have had surprisingly little to say about such creative practices which are inherently boundary-crossing.

These developments are contributing to digital minoritization. This digital minoritization is leading to new forms of 'linguistic insecurity' that might jeopardize the puristic language ideology in the future (Owens, Baker 1984: 337-350; Preston 2013: 304-31; Pálsson 1995: 138; Labov 1966: 336; Mackaulay 1997: 52). ${ }^{26}$ Interviews showed that the influence of English as the digital language had led to linguistic insecurity vis-à-vis Icelandic neologisms. Interviewees were unsure whether they should say 'video' or 'myndband', 'hashtag' or 'myllumerki',

25 The mother told me that each evening she hears her sons shouting in English at the console.

26 Sociolinguists have typically defined linguistic insecurity with reference to class divisions. Meyerhoff (2006: 292) defines it as the feeling that the variety speakers use is somehow inferior, ugly or bad. Wolfram and Schilling-Estes 2006: 398) state it is the belief that " $\mathrm{t}$ ] he language of a socially subordinate group is linguistically deficient [...]”. 
'browser' or 'vafri,' 'selfie' or 'sjálfsmynd'. Older neologisms which predated digital Smartphones such as 'tölvapóstur' ('e-mail'), 'tölva' ('computer'), 'lykilorð’ ('password') and 'lyklaborð' ('keyboard') were much more readily used.

Extract from interview with Einar about language attitudes. Einar is a 24-yearold man who lives in south-east Iceland. (Translated from Icelandic.)

Author: Do you think Iceland's language policy with its objective of keeping the language 'pure' is still working?

Einar: I think people like these new words ('nýyrði'). They are creative, fun and even people my age are keen to use Icelandic words. But the influence of English in digital domains is now overwhelming. It is not that people don't want to speak Icelandic, but the default language of technology is becoming English, I think. You can't police the language of the Internet. It's like a massive wave crashing on our small island.

Author: Are you sometimes unsure whether you should use an Icelandic or English word? Do you think the influence of English is making young Icelanders less confident about their language usage? Can you think of any concrete examples?

Einar: It is difficult to say. When it comes to gaming, I find it more natural to speak in English. Sometimes, I am not sure what the word is in Icelandic. I know some people are not sure how to decline 'SMS' in the plural. I am never sure whether I should say 'sjónvarp í svefnherberginu” or 'sjónvarp á svefnherberginu' ('television in the bedroom') (he laughs). Hopefully, I am not the only one! There are other examples. I was told off once by an old man for declining incorrectly 'cók' ('Coca-cola'). ${ }^{27}$ That was embarrassing (he laughs). I can never remember the new Icelandic word for 'pomegranate. Recently, my dad and my uncle were arguing about the Icelandic word for 'trophy wife. Was it 'steypakona', 'breggjkona' or 'framsýningarfrúa'? (he laughs) But, I am not sure this is because of the influence of English. I think we will continue to speak our language, but the language of many offices in Iceland now is English. If there is only one foreigner, everybody has to switch to English. There is already a kind of bilingualism here.

As we have already seen, ideologically, Iceland wishes to be perceived as egalitarian and devoid of social divisions, but the consequences of its historic language policy seem to highlight social divisions. A culture of grammatical prescription

27 During my earlier fieldwork in particular, a grammatical error was seldom allowed to go unnoticed. On a number of occasions, the desire for grammatical correctness led interlocutors in shops, museums and indeed any public places not only to correct the error, but to cite the whole morphological paradigm with all the respective declensions. It was exclusively older speakers that had a tendency to do this, but the general culture of grammatical correction was to a degree spread across all age groups. A common error is declining the first four cardinal numbers incorrectly. It is often suggested by Icelanders that this leads some speakers to order goods in packets of five in shops. 
and correction has led unsurprisingly to the emergence of linguistic (and as a consequence social) barriers within the Icelandic community itself. One informant told me that he did not think that he would be able to get the job that he wanted if he made a grammatical error. In my earlier research, a number of informants of different ages spoke about the notion of 'málótti' ('fear of speaking'). This refers to a linguistic context where the speaker feels ill at ease for the reason that they believe an interlocutor will correct their grammar (syntax and lexical usage). This is more than just a lack of confidence in one's grammar. It is explicitly a concern that they will be corrected in public, and that this will lead to embarrassment or humiliation. It is conceivable that digital minoritization is serving to enhance further this lexical uncertainty as code-mixing becomes the norm for this digital age ('stafreen öld').

\section{The outcomes of these new developments}

Ideologies of language in Iceland have tried neither to conceal nor recognize these heterogeneous linguistic practices on the ground, and so we cannot yet see how and whether these new developments can be reconciled with the Irvine and Gal model. Presumably, they will be considered a "linguistic other"; a form of speaking that is not Icelandic. Despite the changes in the languagescape, the prevailing ideology in Iceland remains for the moment that of a "homogeneous cultural template" (Woolard 1998: 15). Language planners give the impression that everything might be changing around it, but the Icelandic language remains the same.

It is clear that linguistic purism is on the wane. The battle with syntactic and morphological purism is more or less lost (as evidenced with the proliferation of the 'new passive' form) and foreign words are used frequently by younger speakers (particularly blogs). ${ }^{28}$ Foreign words with Icelandic spelling are prevalent such as 'plis' ('please'), 'sjoppa' ('shop'), 'sorrý' ('sorry'), 'djók' ('joke'). New variants of spoken Icelandic are also beginning to appear as migrants to Iceland learn Icelandic. The most striking development is perhaps that the "erasure" mechanisms are no longer being employed. To my knowledge, translanguaging utterances have not taken up any position within the indexicality hierarchies inherent in fractal recursions either.

The previous discourse of purism and the semiotic processes that underpinned it implied that speaking Icelandic with "impurities" was a threat to the

28 See Friðriksson 2008 for a discussion of examples. 
authenticity of Icelandicness. This linguistic fetishism can still be found $i$ sveit ('in the countryside') where Icelanders believe the "best" Icelandic is spoken. It is considered the best because it is more likely to be free of any foreign linguistic influences. Once again, it is felt that using foreign words undermines the policy of 'holding the thread' ('varðveita tengsl') and would mean Icelandic could no longer be seen as single and bounded diachronically. However, the new variants and their speakers do not appear to be subject to the same constraints of purism as previously. ${ }^{29}$

\section{Conclusion}

Our work has shown that the Icelandic language was "imagined" as homogenous and that this was perceived to correspond with essentialized representations of social groups. It has also examined how linguistic differences (or rather lack of) can be rationalized using a semiotic model. As with other attempts to apply the Irvine and Gal model (Andronis 2003: 263-9; Androutsopoulos 2010: 182-205), the process of iconization has shown that linguistic forms in Iceland are made to be iconic of the social identities of the speakers themselves. There is every reason to believe that these semiotic properties can be observed in all speech communities to some degree.

New discursive practices are at odds with the historic objectives of Iceland's language policy to the extent there has been complete obfuscation of them. Anomalies can be "erased" using the Irvine Gal model, but more pervasive and systemic linguistic transgressions would challenge the ideology from the bottomup. For the first time, Icelanders would be left rationalizing sociolinguistic variation instead of sociolinguistic homogeneity. If language stands in an isomorphic relationship with culture as iconization attempts to show, these recent linguistic practices suggest Iceland has become multicultural and that the "one-languageone-culture" assumption (Irvine 1996: 123) can be fairly questioned.

In conclusion, mapping the sociohistorical linguistic history of Iceland involves undoubtedly semiotic processes. Iconization was at the heart of the

\footnotetext{
29 In particular, Polish migrants (the largest group of migrants in Iceland) I met during my fieldwork spoke of how tolerant Icelanders were to their heavily accented Icelandic. Interestingly, most migrants I met considered Iceland to be bilingual and English to be as essential as Icelandic. In the late 1990s when I first visited Iceland, two per cent of the population were of foreign origin. Today that figure is 12 per cent. 19 per cent of pre-school children in Reykjavík are non-native speakers of Icelandic (Source: Ministry of Education, Science and Culture, Iceland).
} 
essentializing scheme which drove Icelandic language policy with its focus on ensuring linguistic "anomalies" such as "genitive phobia" indexed essential differences. As far as Icelandic is concerned, one weakness of the Irvine Gal social semiotic model is the lack of distinction between the semiotic processes of iconization and fractal recursivity. With fractal recursion, we are looking for ideological patterns recurring at different levels of society. It is not obvious what these "progressive patterns of recurrence" would be in Iceland. The pure/impure linguistic distinction inherent in language policy has not led to attempts to reproduce other societal dichotomies. The overall aim of Iceland's linguistic ideology is to represent a holistic image of one collective nation rooted in a unique country bound by a uniform, ancient language. Conspicuous linguistic foreignness can be iconized, but deep societal distinctions implied in a process of fractal recursivity would render the ideology ambiguous and redundant.

In Iceland, the binaries were simple (i.e. not based on indexicality hieararchies): "impure" language (such as "dative disease" and use of sléttur) indexed un-Icelandicness. One might argue that this resulted in mimetic patterning in wider relational fields, un-Icelandicness representing lack of social morals etc., but that was not explicit in "categorisating cultural objects" (Gal 2002: 80). For it to be fully fractal recursive, I would expect to see a multiple-layered set of oppositions at smaller scales (Irvine, Gal 2000: 35-8). On the basis of the Icelandic data set at least - an overt monoglot ideology, - it is difficult to see why this third semiotic process should be called 'fractal recursivity', and not just 'recursion'. Elsewhere in sociolinguistically complex societies, there is clearer evidence of recursion: as an example, ethnolectal German (associated with poor taste in music; problem youth) versus Standard German (standard pop music; "normal" upbringing) (Androutsopoulos 2010: 197-98). Fractal recursivity is perhaps easier to identify in language cultures that are heterogenous and and not influenced by linguistic purism. This withstanding, the social semiotic model is a very useful framework for understanding the function of language ideologies.

Ackowledgements. An earlier version of the paper was presented at the University of Trondheim in 2014. I am very grateful for all the excellent feedback I received at that seminar and to all my colleagues in Iceland who have fed into the ideas presented here over the years. I am of course extremely grateful to all the Icelanders that assisted me in my research. There can be few speech communities that show such a love and passion for their mother tongue. The first part of this sociolinguistic research was funded by a grant from the Arts and Humanities Research Council (AHRC) of Great Britain. 


\section{References}

Anderson, Benedict 1991. Imagined Communities: Reflections on the Origins and Spread of Nationalism. (2nd edition.) London: Verso.

Andronis, Mary Antonia 2003. Iconization, fractal recursivity, and erasure: Linguistic ideologies and standardisation in Quichua-speaking Ecuador. Proceedings of the Eleventh Annual Symposium about Language and Society. Texas Linguistic Forum 47: 263-269.

Androutsopoulos, Jannis 2010. Ideologizing ethnolectal German. In: Johnson, Sally; Milani, Tommaso M. (eds.), Language Ideologies and Media Discourse: Texts, Practices, Politics. London: Continuum, 182-205.

Auer, Peter 1995. The pragmatics of code-switching: A sequential approach. In: Milroy, Lesley; Muysken, Pieter (eds.) One Speaker, Two Languages: Cross-Disciplinary Perspectives on Code-Switching. Cambridge: Cambridge University Press, 115-135. https://doi.org/10.1017/CBO9780511620867.006

Bauman, Richard; Briggs, Charles 2009. Voices of Modernity: Language Ideologies and the Politics of Inequality. Cambridge: Cambridge University Press.

Baynham, Mike; Lee, Tong King 2019. Translation and Translanguaging. (New Perspectives in Translation and Interpreting Studies.) Abingdon: Routledge. https://doi.org/ $10.4324 / 9781315158877$

Blommaert, Jan 2005. Discourse: A Critical Introduction. Cambridge: Cambridge University Press. https://doi.org/10.1017/CBO9780511610295

Blommaert, Jan; Rampton, Ben 2012. Language and Superdiversity. MMG Working Paper, 12-05, 1-30.

Briggs, Charles. 1998. 'You're a liar - you're just like a woman!': constructing dominant ideologies of language in Warao men's gossip. In: Schieffelin, Bambi B..; Woolard, Kathryn A.; Kroskrity, Paul V. (eds.), Language Ideologies: Practice and Theory. Oxford: Oxford University Press, 229-255.

Bucholtz, Mary; Hall, Kira. 2008. All of the above: New coalitions in sociocultural linguistics. Journal of Sociolinguistics 12(4): 401-431. https://doi.org/10.1111/j.1467-9841. 2008.00382.x

Cameron, Deborah 2006. Ideology and language. Journal of Political Ideologies 11(2): 141-152. https://doi.org/10.1080/13569310600687916

Dorian, Nancy C. 1981. Language Death: The Life Cycle of a Scottish Gaelic Dialect. Philadelphia: University of Pennsylvania Press. https://doi.org/10.9783/9781512815580

Douglas, Mary 1966. Purity and Danger: An Analysis of Concepts of Pollution and Taboo. London: Routledge.

Durkheim, Émile 1912. The Elementary Forms of Religious Life. (Swain, Joseph Ward, trans.) London: George, Allen \& Unwin.

Eckert, Penelope 2008. Variation and the indexical field. Journal of Sociolinguistics 12(4): 453-476. https://doi.org/10.1111/j.1467-9841.2008.00374.x

Eckert, Penelope 2012. Three waves of variation study: The emergence of meaning in the study of sociolinguistic variation. Annual Review of Anthropology 41: 87-100. https:// doi.org/10.1146/annurev-anthro-092611-145828 
Friðriksson, Finnur 2008. Language Change vs. Stability in Conservative Language Communities: A Case Study of Icelandic. Phd Dissertation. (Gothenburg Monographs in Linguistics 37.) University of Gothenburg.

Gal, Susan 2002. A semiotics of the public/private distinction. Differences: A Journal of Feminist Cultural Studies 13: 77-95. https://doi.org/10.1215/10407391-13-1-77

Gal, Susan; Irvine, Judith T. 2019. Signs of Difference: Language and Ideology in Social Life. Cambridge: Cambridge University Press. https://doi.org/10.1017/9781108649209

García, Ofelia; Wei, Li 2013. Translanguaging: Language, Bilingualism and Education. London: Palgrave Macmillan. https://doi.org/10.1057/9781137385765_4

Guðfinnsson, Björn 1946. Mállýzkur I-II. Reykjavík: Ísafoldarprentsmiðja.

Guðmundsson, Helgi 1972. Pronominal Dual in Icelandic. Reykjavík: Institute of Nordic Linguistics.

Halldórsson, Halldór 1979. Icelandic purism and its history. Word 30: 76-86.

Hansen, Karolina; Wypych, Michał; Bańko, Mirosław; Bilewicz, Michał 2017. Psychological determinants of linguistic purism: National identification, conservatism, and attitudes to loanwords. Journal of Language and Social Psychology 37(3): 365-375. https://doi. org/10.1177/0261927X17737810

Helgason, Agnar 2000a. mtDNA and the origin of the Icelanders: Deciphering signals of recent population history. American Journal of Human Genetics 66: 999-1016. https:// doi.org/10.1086/318785

Helgason, Agnar 2000b. Estimating Scandinavian and Gaelic ancestry in the male settlers of Iceland. American Journal of Human Genetics 67: 697-717. https://doi. org/10.1086/303046

Heller, Monica 1999. Linguistic Minorities and Modernity: A Sociolinguistic Ethnography. London: Longman.

Heller, Monica 2008. Doing ethnography. In: Wei, Li; Moyer, Melissa G. (eds.) The Blackwell Guide to Research Methods in Bilingualism and Multilingualism. Oxford: Blackwell Publishing, 249-262. https://doi.org/10.1002/9781444301120.ch14

Hill, Jane H. 1985. The grammar of consciousness and the consciousness of grammar. American Ethnologist 12(4): 725-737. https://doi.org/10.1111/amet.12629

Hilmarsson-Dunn, Amanda; Kristinsson, Ari Páll 2013. The language situation in Iceland. In: Kaplan, Robert B.; Baldauf, Richard B.; Kangwangamalu, Nkonko M. (eds.), Language Planning in Europe: Cyprus, Iceland and Luxembourg. Abingdon: Routledge, 207-276. https://doi.org/10.1080/14664208.2010.538008

Horner, Kristine 2005. Reimagining the nation: Discourses of language purism in Luxembourg. In: Langer, Nils; Davies, Winifred V. (eds.), Linguistic Purism in the Germanic Languages. (Studia Linguistica Germanica 75.) Berlin: De Gruyter, 166-185. https:// doi.org/10.1515/9783110901351.166

Horner, Kristine 2007. Global challenges to nationalist ideologies: Language and education in the Luxembourg Press. In: Johnson, Sally; Ensslin, Astrid (eds.), Language in the Media: Representations, Identities, Ideologies. (Advances in Sociolinguistics.) London: Bloomsbury, 130-146.

Irvine, Judith T. 1996. Language and community: Introduction. Journal of Linguistic Anthropology 6(2): 123-125. https://doi.org/10.1525/jlin.1996.6.2.123

Irvine, Judith T.; Gal, Susan 2000. Language ideology and linguistic differentiation. In: Kroskrity, Paul V. (ed.), Regimes of Language: Ideologies, Polities, and Identities. (School 
of American Research Advanced Seminar Series.) Santa Fe: School of American Research Press, 35-84.

Joseph, John 2004. Language and Identity: National, Ethnic, Religious. London: Palgrave. Kjartansson, Helgi Skúli 1979. Eignarfallsflótti: Uppástunga um nýja málvillu. Íslenskt mál 1: 88-95.

Kroskrity, Paul 1998. Arizona Tewa Kiva speech as a manifestation of a dominant language ideology. In: Schieffelin, Bambi B.; Woolard, Kathryn A.; Kroskrity, P. V. (eds.), Language Ideologies: Practice and Theory. (Oxford Studies in Anthropological Linguistics.) Oxford: Oxford University Press, 103-122.

Kroskrity, Paul 2004. Language ideology. In: Duranti, Alessandro (ed.), A Companion to Linguistic Anthropology. (Blackwell Companions to Anthropology 1.) Malden, Oxford, Victoria: Blackwell, 496-517.

Kroskrity, Paul 2010. Language ideologies - Evolving perspectives. In: Jaspers, Jürgen; Östman, Jan-Ola; Verschueren, Jef(eds.), Society and Language Use. (Handbook of Pragmatics Highlights 7.) Amsterdam: John Benjamins Publishing Company, 192-211. https://doi.org/10.1075/hoph.7.13kro

Kroskrity, Paul. V.; Field, Margaret C. (eds.) 2009. Native American Language Ideologies: Beliefs, Practices, and Struggles in Indian Country. Tucson: The University of Arizona Press.

Kvaran, Guðrún 2005. Social stratification in the present day Nordic languages IV: Icelandic. In: Bandle, Oskar; Braunmüller, Kurt; Jahr, Ernst Hakon; Karker, Allan; Naumann, Hans-Peter; Teleman, Ulf; Elmevik, Lennart; Widmark, Gun. (eds.), The Nordic Languages: An International Handbook of the History of the North Germanic Languages. Vol. 2. (Handbooks of Linguistic and Communication Science, HSK 22/2.) Berlin: Walter de Gruyter, 1788-1794.

Labov, William 1966. The Social Stratification of English in New York City. Washington: Center for Applied Linguistics.

Labov, William 1972. Sociolinguistic Patterns. Philadelphia: University of Pennsylvania Press.

Lave, Jean; Wenger, Etienne 1991. Situated Learning: Legitimate Peripheral Participation. New York: Cambridge University Press. https://doi.org/10.1017/CBO9780511815355

Leonard, Stephen Pax 2011. Relative linguistic homogeneity in a New Society: The case of Iceland. Language in Society 40(2): 169-186. https://doi.org/10.1017/ S0047404511000029

Leonard, Stephen Pax 2012. Language, Society and Identity in early Iceland. Oxford: Wiley Blackwell.

Leonard, Stephen Pax; Árnason, Kristján 2011. Language ideology and standardisation in Iceland. In: Kristiansen, Tore; Coupland, Nikolas (eds.), Standard Languages and Language Standards in a Changing Europe. Oslo: Novus, 91-96.

Mackaulay, Ronald 1997. Standards and Variation in Urban Speech. Amsterdam: John Benjamins Publishing Company.

Maling, Joan; Sigurjónsdóttir, Sigríður 2002. The new impersonal construction in Icelandic. Journal of Comparative Germanic Linguistics 5: 97-142. http://doi.org./10.1023/A: 1021224923742

Meyerhoff, Miriam 2006. Introducing Sociolinguistics. London: Routledge. https://doi. org/10.4324/9780203966709 
Milani, Tommaso M. 2008. Language testing and citizenship: a language ideological debate in Sweden. Language in Society 37(1): 27-59. https://doi.org/10.1017/S0047404508080020

Milroy, James 2001. Language ideologies and the consequences of standardization. Journal of Sociolinguistics 5/4: 530-555. https://doi.org./10.1111/1467-9481.00163

Ochs, Elinor 1996. Linguistic resources for socializing humanity. In: Gumperz, John J.; Levinson, Stephen C. (eds.), Rethinking Linguistic Relativity. (Studies in the Social and Cultural Foundations of Language 17.) Cambridge: Cambridge University Press, 407-438.

Owens, Thompson W.; Baker, Paul M. 1984. Linguistic insecurity in Winnipeg: Validation of a Canadian index of linguistic insecurity. Language in Society 13(3): 337-350. https://doi.org/10.1017/S0047404500010538

Pratt, Mary Louise 2011. Comparative literature and the global languagescape. In: Behdad, Ali; Thomas, Dominic (eds.), A Companion to Comparative Literature. (Blackwell Companions to Literature and Culture.) Malden, Oxford, Chichester: Wiley, 273-295. https://doi.org./10.1002/9781444342789.ch18

Preston, Dennis 2013. Linguistic insecurity forty years later. Journal of English Linguistics 41(4): 304-331. https://doi.org/10.1177/0075424213502810

Pálsson, Gísli 1989. Language and society: The ethnolinguistics of Icelanders. In: Durrenberger, E. Paul; Pálsson, Gísli (eds.), The Anthropology of Iceland. Iowa City: University of Iowa Press, 121-139. https://doi.org/10.2307/j.ctt20fw942.11

Pálsson, Gísli 1995. The Textual Life of Savants: Ethnography, Iceland and the Linguistic Turn. (Studies in Anthropology and History 18.) London: Routledge.

Rampton, Ben 1998. Speech community. In: Verschueren, Jef; Östman, Jan-Ola; Blommaert, Jan (eds.), Handbook of Pragmatics, 1998 Installment. Amsterdam: John Benjamins, 1-30. https://doi.org/10.1075/hop.4.spe2

Rehm, Georg; Uszkoreit, Hans 2012. META-NET White Paper Series. [31 Volumes.] Berlin: Springer. https://doi.org/10.1007/978-3-642-30174-2_5

Rögnvaldsson, Eírikur 1983. Págufallssýkin og fallakerfi íslensku. Skíma 16: 3-6.

Sigurjónsdóttir, Sigríður; Maling, Joan 2001. Рað var hrint mér á leiðinni í skólann: polmynd eða ekki polmynd? ["It was pushed me on my way to school:" Passive or not Passive?] Íslenskt mál 23: 123-180.

Sigurjónsdóttir, Sigríður; Nowenstein, Iris E.; Björnsdóttir, Sigríður; Angantýsson, Ásgrimur; Ingason, Artur Karl; Rögnvaldsson, Eiríkur 2017. Language Contact without Contact: A Nationwide Study of Digital Minoritization. DiGS 19 contact workshop. September 5-8.

Sigurjónsdóttir, Sigríður; Nowenstein, Iris 2016. Passives and the "new impersonal" construction in Icelandic language acquisition. In: Perkins, Laurel; Dudley, Rachel; Gerard Juliana; Hitczenko, Kasia (eds.), Proceedings of the 6th Conference on Generative Approaches to Language Acquisition in North America (GALANA 2015). Somerville, Massachusetts, 1-13.

Silverstein, Michael 1979. Language structure and linguistic ideology. In: Clyne, Paul R.; Hanks, William F.; Hofbauer, Carol L. (eds.), The Elements: A Parasession on Linguistic Units and Levels. Chicago: Chicago Linguistic Society, 193-247. 
Svavarsdóttir, Ásta 1982. Págufallssýki: breytingar á fallnotkun í frumlagssæti ópersónulegra setninga. Íslenskt mál 4: 19-62.

Thurlow, Crispin 2017. 'Forget about the words'? Tracking the language, media and semiotic ideologies of digital discourse: The case of sexting. Language \& Communication 20: 10-19. https://doi.org/10.1016/j.dcm.2017.06.008

Valeri, Valerio 2000. The Forest of Taboos: Morality, Hunting and Identity among the Huaulu of the Moluccas. Madison: University of Wisconsin Press.

Voloshinov, Valentin N. 1972. Marxism and the Philosophy of Language. New York: Seminar Press.

Vygotsky, Lev1962. Thought and Language. (Studies in Communication Series) (Hanfmann, Eugenia; Vakar, Gertruda, trans.) New York: Wiley. Cambridge: Massachusetts Institute of Technology Press-.

Wei, Li 2011. Moment analysis and translanguaging space: Discursive construction of identities by multilingual Chinese youth in Britain. Journal of Pragmatics 43: 12221235. https://doi.org/10.1016/j.pragma.2010.07.035

Wolfram, Wolfram; Schilling-Estes, Natalie 2006. American English. Oxford: Blackwell.

Woolard, Kathryn A. 1998. Introduction: Language ideology as a field of inquiry. In: Schieffelin, Bambi B.; Woolard, Kathryn A.; Kroskrity, Paul V. (eds.), Language Ideologies: Practice and Theory. New York: Oxford University Press, 3-30.

Woolard, Kathryn A.; Schieffelin, Bambi. B. 1994. Language ideology. Annual Review of Anthropology 23: 55-82. https://doi.org/10.1146/annurev.23.100194.000415

\section{Семиотический подход к языковым идеологиям: моделирование меняющегося языкового пейзажа Исландии}

Неоднократно были предприняты попытки изучить с помощью методов социосемиотики, как при говорении оформляются языковые варианты. Используя этнографические данные, собранные на протяжении многих лет, в статье эта модель применяется к Исландии, которую называют «E. coli лингвистики» - eе размер, изолированность и относительная языковая однородность создают условия, аналогичные социо-лингвистической лаборатории. Подобная семиотическая модель языковых идеологий проблематизирует лингвистический пуризм во времена социолингвистических переворотов. Анализ показывает, как находящаяся в центре исландской языковой политики эссенциализирующая схема обеспечила, что лингвистические «аномалии», такие как «заболевание датива» и «фобия генитива», указали на существенные различия. «Нечистый» язык указывал на неисландца. Когда-то одноязычное (на самом деле однодиалектное) языковое сообщество Исландии сейчасвсебольшехарактеризуют инновационныелингвистическиетрансгрессии, которые до сих пор не инструментализированы разработчиками языковой политики. Показывается, как семиотическая модель может помочь нам проанализировать функцию языковых идеологий в более широком смысле. 


\section{Semiootiline lähenemine keeleideoloogiatele: Islandi muutuva keelemaastiku modelleerimine}

On tehtud katseid uurida, kuidas kõnelejad raamivad keelevariante, rakendades sotsiosemiootilisi meetodeid. Aastate vältel kogutud etnograafilisi andmeid kasutades rakendab artikkel seda mudelit Islandi puhul, mida on nimetatud ka "lingvistika E. coli"-ks - Islandi suurus, ajalooline isoleeritus ning suhteline keeleline homogeensus loovad seal sotsiolingvistikalaboratooriumiga võrreldavad tingimused. See keeleideoloogiate semiootiline mudel problematiseerib keelepurismi sotsiolingvistiliste murrangute ajastul. Analüüsist ilmneb, kuidas Islandi keelepoliitika keskmeks olev essentsialiseeriv skeem kindlustas selle, et keelelised "anomaaliad" nagu "daativitõbi" ja "genitiivifoobia" osutasid olemuslikele erinevustele. "Ebapuhas” keel viitas ebaislandlikkusele. Millalgi ükskeelset (tegelikult ka ühedialektilist) Islandi kõnekogukonda iseloomustavad üha enam uuenduslikud lingvistilised transgressioonid, mida keelepoliitika loojad pole senini instrumentaliseerinud. Näidatakse, kuidas semiootiline mudel võib meil aidata laiemalt analüüsida keeleideoloogiate funktsiooni. 